\title{
Impact Of Dividend Policy On Share Price Valuation In Nigerian Banks
}

\author{
Stephen Bassey Duke \\ Ph.D Scholar Department of Banking and finance \\ University of Calabar, Cross River State Nigeria \\ Nneji Ikenna D. \\ Ph.D Scholar Department of Banking and finance \\ University of Calabar, Cross River State Nigeria \\ Nkamare S. E. \\ PHd Scholar Department of Banking and finance \\ University of Calabar, Cross River State Nigeria
}

\begin{abstract}
This study investigated the impact of dividend policy on share price valuation in Nigerian banks. This was done by utilising data on two banks operating in the Nigerian economy (GTBank and United Bank for Africa). The data used for this study are market price, dividend yield and retention ratio. Market price was the dependent variable while dividend yield and retention ratio were included in the independent variables. In order to accomplish the set out objectives of this study, two research hypotheses $\left(\mathrm{H}_{01}-\mathrm{H}_{02}\right)$ were formulated which were tested via a number of analytical techniques. These are the ADF Unit Root Test and the ordinary least squares test. These tests were carried out with the aid of e-views software package. Based on the results gotten, the null forms of both hypotheses were rejected while the alternate forms were accepted. The results revealed that dividend yield had a significantly positive effect on share price while retention ratio was found to have a significantly negative effect on it. The study ended by giving recommendations which include: Banks should ensure that they have an optimal robust dividend policy in place. Regular update of records of shareholders should be made to avoid a deliberate diversion or undue retention of unclaimed dividend warrants. Government should set up a body that will help to manage unclaimed dividends and also ensure that situations that give rise to such are minimized
\end{abstract}

Keywords: Share-price, Dividend Policy, Dividend yield, Retention ratio

\section{Background of the Study}

\section{INTRODUCTION}

All corporate organisations, banks inclusive, have three major decisions to make if they must work in the interest of achieving their fundamental objective of maximizing their shareholders' wealth. These decisions are on the kind of investments to undertake (investment decision), how to finance these investments (financing decision) and what to do with the profits realised (dividend decision) i.e. what amount of profit to be paid out as dividend to shareholders and what amount to be retained for further investment purposes [6]. Investment decisions determine the total value and types of assets an organization utilizes. Financing decisions determine the capital structure of the firm and forms the source on which 
investment decisions are made. The third decision, dividend decision, which forms the focus of this study, has to do with the determination of the dividend payout policy adopted by the firm in deciphering the amount of cash that is given to shareholders. This decision is dependent on whether the potential investors and share-holders alike have a preference for capital gains as opposed to income.

Therefore, corporate organisations adopt dividend policies that have the major aim of maximising share holders' wealth or, put in a better perspective, increasing their share price/value. The financial managers, for instance, have to decide on whether to adopt a high payout ratio and turn around to borrow funds from the capital market for investment purposes or adopt a low payout ratio and use the retained earnings in financing the investment opportunities prevalent at that time [24]. Others also adopt the method of paying stock dividends as well as cash dividends depending on their shareholders' preference. The particular method a firm adopts also depends on the prevailing economic situation at that time.

Dividend policy can be seen as a pivot around which other financial policies operate since the other two decisions a manger is faced with revolve around it. The financing decision and investment decision are both dependent on the amount of retained earnings available and this is influenced by the dividend policy [1]. Dividend policy is thus one of the most important policies in corporate financing not only from the firms' viewpoint, but also from the point of view of shareholders, regulatory bodies and other stakeholders.

Over the years, the importance of dividend policy in determining the share price or value has been one of the most debated topics in the world of finance as it has remained a very puzzling issue. Scholars have engaged in extensive researches to explain why banks and other corporate bodies alike should attach importance or not to the kind of dividend policy they adopt. Other researchers have developed empirical tested models to explain dividend behaviour. It is against this background that this study attempted to empirically investigate the impact of dividend policy on the valuation of shares in Nigerian banks.

\subsection{Statement of the Problem}

Corporate organisations, banks inclusive are faced with the problem of whether to pay a large, small or zero percentage of their earnings as dividends Vis -a-Vis financing future investments projects. This problem is borne out of the desire to satisfy the various needs of shareholders. Some shareholders have the need for income now and as such will prefer a high dividend payout ratio, while others who need to investment in the future would prefer capital gains. Due to the fact of having to deal with competing interests of various shareholders, the kind of dividend policy a bank adopts could either lead to positive or negative effects on the share prices of the company. The managers are therefore unable to forecast with certainty to what extent the policy will affect their share prices of their firms. Therefore the followings questions trouble the financial managers;

- Should the bank pay out money to its shareholders or invest it for them?

- If dividend payment is decided upon, what percentage of its earnings is actually paid?

- Consequent upon the above decisions, how will the share price of the firm be affected?

There are two distinct and opposing theories on dividend policy and its effect on firm value, namely, the dividend irrelevancy theory and the dividend relevancy theory. These two theories ignited the dividend policy controversy among scholars as to whether dividend policy affects share price/value of a corporate body. 
Lintner [17], Baker and Wurgler [6] are among financial scholars whom found out that dividend policy does affect the value of the firm and is thus relevant. On the other side of the divide, Miller and Modigliani [20], Miller and Rock [21] have theoretically explained that the value of the firm is unaffected by dividend policy and as such dividend policy is irrelevant. In the world today, many academicians and corporate managers alike still debate whether the dividend policy matters.

Despite several decades of research in developed countries developing countries such as Nigeria are still lacking in extensive research on this topic. This paper is thus an attempt to address these issues and categorically determine the impact dividend policy has on share value of Nigerian banks.

\subsection{Objectives of the Study}

The general objective of this study was to examine the impact of dividend policy on share price valuation in Nigerian banks. Specifically, this study sought to;

- Ascertain if there is any significant relationship between dividend yield and share price of Nigerian banks.

- Determine the impact of retained earnings ratio on the share price of Nigerian banks.

\subsection{Research Question}

Based on the objectives of this study, the following research questions guided the study;

- What is the relationship between dividend yield and banks' share price?

- What is the impact of retained earnings ratio on the share price of Nigerian banks?

\subsection{Research Hypothesis}

In order to provide a framework for evaluating the impact of dividend policy on share price valuation of Nigerian banks the following hypotheses were formulated in null form

Ho1: There is no significant relationship between dividend yield and share price of banks in Nigeria.

Ho2: There is no significant impact of retained earnings ratio on share price of banks in Nigeria.

\subsection{Significance of the Study}

The study is beneficial to many groups. It is important to note that the study provides an avenue for an in-depth understanding of the topic by students, financial managers, board of directors and other decision makers in formulating optimum policies for their respective banks.

The study also forms as a tool for assisting investors in making their investment decisions as well as aiding to expose the various factors that may influence stock prices. The study further serves as research materials for future investors and also adds to the existing body of knowledge.

\subsection{Scope of the Study}

The scope of this study spanned a period from 2003-2013, having 11 years period for the scope of this study. The study also focused on 2 Nigerian banks (one new generation and the other old generation) in an attempt to empirically analyse the effect of dividend policy on share price valuation. This scope was expected to give an accurate analysis and findings on the subject matter. 


\subsection{Organisation of the Study}

The study is segmented into five [5] sections for effective achievement of objectives. Section one serves as the general introduction of the study, it features subsections on the background of the study, statement of the problem, objectives of the study research questions, hypotheses, significance of the study, scope of the study and definition of terms.

Section two encompasses a review of the literature related to the study area. The theoretical framework, made of the relevant theories, is also discussed here. Section three presented the methodology to be employed in the analysis of the study and it included the research design, sources of data, method of data collection, techniques of data analysis and model specification.

Section four embodied the presentation of data, analysis and discussion of findings. Section five is made of the summary of findings, conclusion and recommendations.

\subsection{Definition of Terms}

The following terms are operationally defined:

I. Dividend: This is defined as that portion of a company's net earnings that accrues to shareholders as a result of the money invested in acquiring the stock of a given company [9]. It is usually expressed as a percentage of nominal value of the company's ordinary share capital or as a fixed amount per share.

II. Dividend policy: This is concerned with the division of net profit after taxes between payments to shareholders (ordinary shareholders) and retention for reinvestment on behalf of the shareholders [15]. It is thus the trade-off between retained earnings on one hand and paying out cash on the other hand.

III. Dividend per Share: This is the earnings distributed to ordinary shareholders divided by the number of ordinary shares outstanding.

IV. Earnings Per Share: This is the ratio showing the net profit per issued share or per share entitled to a dividend

V. Dividend Yield: This ratio indicates the earnings (in form of dividends) on investment in shares. It is also called the dividend-price ratio as it calculated by dividing dividend per share by the price per share.

VI. Retention Ratio: This is the ratio that shows the percentage of earnings held back and not paid out as dividend. It is the opposite of dividend payout ratio.

\subsection{Theoretical framework}

\section{THEORETICAL FRAMEWORK AND LITERATURE REVIEW}

There are three theories of dividend policy and these theories have been argued generally by various authors in finance so as to arrive at a consensus on which is valid. Some would argue that the amount of the dividend is irrelevant, and anytime spent on that decision is a waste of energy. Others contend that a high dividend will result in a high stock price while others take the view that dividends actually hunt the stock value [25]. The theories are categorized into residual theory of dividend policy, dividend irrelevance theory and the bird-in-the hand theory of dividend policy.

\subsubsection{Residual theory}

This theory was advanced by the imperfect market school of thought. It holds that dividends are paid only after internal investment opportunities have been exhausted. Even if the 
available investment opportunities are more than the firm's earnings, the firm should borrow in order to cater to all the investment opportunities. If no earnings remains after the investment decisions have been made, then, no dividend is paid. The essence of the residual theory of dividend policy is that the firm will pay dividend from residual earnings that is from earnings left over after all suitable investment opportunities have been financed. i.e the decision to pay dividends is purely residual. Here shareholders prefer capital gains to dividend payments and as such retaining earning are the most important source of financing for most companies. According to Weston and Brigham [29], the starting point in the theory is that investors prefer to have the firm retain and reinvest earnings rather than pay them out as dividend if the return on reinvested earning exceeds the rate of return the investor could, himself obtain on the investments of comparable risk. Thus, the residual theory of dividends considers dividend policy as a residual or passive decision.

Two factors that lend support to this theory are the tax bias in favour of capital gains and the presence of dividend payout costs which make dividend payments less attractive as a means of compensation. Thus, according to this theory, a firm should have a stable level of dividend policy irrespective of whether it experienced a boom or gloom in terms of profit realized. As such the firm saves more during periods of high profit in order to cater to the payment of dividends during periods of losses.

\subsubsection{Dividend irreverence theory}

This theory was advanced by the perfect market school of thought pioneered by the works of Modigliani and Miller. It asserts that a firm's dividend policy has no effect on its value or its cost of capital. The theory of dividend irrelevance was perhaps most elegantly argued by its chief proponents, Modigliani and Miller (usually referred to as $\mathrm{M}$ and $\mathrm{M}$ ) in their seminar paper in 1961.

Miller and Modgliani [20] advanced the theory according to which, in perfect capital markets populated by rational investors, a firm's value is solely a function of the firm's investment opportunities and is independent of payout policy. Here, even if a firm pays out all of its earnings as dividend, it can raise funds it might need easily from the capital market since the cost of capital is assumed the same for both internal and external funds. On their views on dividend policy, they postulated an assumption that trading is frictionless so that investors can invest or liquidate their investment in a firm without incurring any direct frictions. When trading friction exist in financial markets, an immediate implication of $\mathrm{M}$ and $\mathrm{M}$ is that other things remain constant, firms with less liquid shares are more inclined to pay dividend relative to firms with more liquid share. Based on this idea, Ghosh and Subrata [12] find a strong empirical relationship between dividend policy of the firm and the liquidity of its common stock. Shareholders too are indifferent as dividend policy doesn't affect their wealth. The value of the firm is rather influenced by the earnings or investment policy the firm undertakes.

\subsubsection{The bird-in-the hand theory}

This theory was advanced by Lintner [18] and Gordon [11] and the essence of the theory is that shareholders are risk-averse and prefer to receive dividend payments rather than future capital gains. Shareholders consider dividend payments to be more certain than future capital gains - thus a "bird in the hand is worth more than two in the bush". The bird here refers to the dividend payment while the bush here refers to the capital gain. Gordon [11] contained that the payment of current dividend resolves the problem of investor uncertainty. Investors have a preference for a certain level of income now rather than the prospect of a higher, but less certain, income at some time in the future. The key implication, as argued by Lintner and Gordon, is that because of the less risky nature dividends, shareholders and investors will 
discount the firm's dividend stream at a lower rate of return, thus, increasing the value of the firm's shares. This is because, as a firm's payout ratio increases, investors will become increasingly concerned that the firms future capital gains will dissipate since the retained earnings that the firm reinvests will be a lot less.

\subsection{Review of related literature}

This section aptly begins with the works of Modigliani and Miller (M\&M). M\&M [20] observed that in a perfect world, dividend policy is irrelevant. They made assumptions like lack of taxes and transaction costs in order to arrive at this conclusion. However their position changed in a later paper they wrote after taking into consideration the effect of taxes. Agrawal and Jayaraman [4] observed that Dividend payments and leverage policy are substitute mechanism for controlling the agency cost of free cash flow. Holder, Langrehr and Hexter [14] found out that firms with greater free cash flow need to pay more dividends to reduce the agency cost associated with it. Oyejide [23], in his study found a statistical significant relationship between current year dividends and past year net profit. Adelegan [2] pointed out that factors such as after tax earnings, economics policy changes, firm's growth potentials and long term debts influence the dividends policy of quoted firms in Nigeria. Adelegan [3] also found out that the cumulative excess returns for dividend paying firms were positive and significant for 30 days from the day of the announcement of dividend payments, while the same excess returns for dividend omitting firms for the same period were significantly negative.

Litzenberger and Ramaswamy [19] argued that investors want companies to retain earnings and thus provide returns in the form of lower-taxed capital gains rather than heavily taxed dividends. In other words, low dividend payout ratio lowers the required rate of return and increases the market value of the firm's shares. Frankfurter and Wood [10] assume that investors maximize after tax income. In a partial equilibrium framework, investors have two choices. Individuals choose the amount of personal and corporate distributions as dividends or capital gains. They reasoned that if the effective marginal capital gains tax paid by shareholders is less than the marginal rate of tax that would be paid on income from dividends then a shareholder is better off with zero dividends. For example if capital gains tax is higher than tax paid on dividends then investors would like the company to retain earnings. Benaruzi [7] extends Frankfurter and Wood [10] results by considering how the prices of stocks might be affected by different dividend policies. He assumed that the market prices of stocks would adjust in such a way that the after tax rate of return received by holders of a company's stock would be the same no matter what dividend policy the company adopts. Kwan [16] observed that larger firms with higher profitability and low growth opportunities have a greater propensity to pay dividends. From the works of Asem [5] it can be seen, via stock market evidence, that profits are lower among dividend-paying firms than their non-paying counterparts. Uwuigbe, Jafaru \& Ajayi, [28] found out that there is a significant positive association between the performance of firms and the dividend payout of the sampled firms in Nigeria. The empirical results of the study by Hashemijoo, Ardekani, \& Younesi, [13] showed a significant negative relationship between share price volatility and two measurements of dividend policy which are dividend yield and dividend payout ratio.

Adefila, Oladapo and Adeoti [1], in their own study, found no correlation between dividend payment and share prices of Nigerian firms as share price fixing, according to them is regulated by the Security and Exchange Commission (S.E.C) in respect of the quoted companies. But then, their findings show that Nigerian firms do have a dividend policy that is dependent on earnings albeit inconsistently. Zulfiqar and Asgher [30] examined the relationship between dividend policy and share prices in Pakistan stock market. Price volatility was used a dependent variable while dividend yield, and earning volatility as independent variables. Murhadi [22] examined 
the relationship between dividend policy and share price changes in UK stock market. Share price was used a dependent variable and debt level, size, growth rate, earning per share was used as independent variables. They used a multiple regression analysis to explore the relation between share price changes and both dividend yield and dividend payout ratio. Results showed price volatility with the two main measures of dividend policy, dividend yield and dividend payout ratio.

Shabibi and Ramesh [27] examined the factors which affect dividend policy for non-financial UK companies. Share price was used dependent variable and risk, industry type and corporate governance factors were used as independent variables. Their result indicated a highly positive and significant correlation between firms' share price and dividend policy.

\subsection{Research Design}

\section{RESEARCH METHODOLOGY}

Research design is the approach or scheme which defines the tools and strategies of the research. In this study, the descriptive and causal research design [26] is employed to empirically determine the impact dividend policy has on share price valuation in Nigerian banks.

\subsection{Sources of Data}

Two major sources of data exist in all research works. These are the primary sources and the secondary sources. Primary sources entail the use of questionnaires to gather data needed while secondary sources consist of utilising already existing data used for some other work but were found to be useful in this study. Based on the objectives of the study, the secondary sources of data are employed in this research. This entailed gathering of information from the annual reports of the banks under consideration and websites.

\subsection{Methods of Data Collection}

This paper made use of the desk research method. This is a method of data collection in which data was gotten from government agency publications and internet this study employed desk survey. In this method, data were collected from annual report of UBA and GTBank and the internet.

\subsection{Techniques of Data Analysis}

This model is analysed using ADF unit root test and regression analysis. The ordinary least square (OLS) model of multiple regression technique was used to establish the relationship between dependent and independent variables.

\subsection{Model Specification}

In this study, taking a cue from the works of Chowdhury and Ahmed [8], share price of the bank was used as the dependent variable. The dividend yield and retained earnings ratio were used as the independent variables. The model specification of the study is thus given below.

$\begin{array}{ll}\mathrm{MP}= & \text { bo }+\mathrm{b}_{1} \mathrm{DY}+\mathrm{b}_{2} \mathrm{RR}+\mathrm{U}_{\mathrm{T}} \\ \text { Where } & \\ \mathrm{MP}= & \text { Market Price } \\ \mathrm{DY}= & \text { Dividend yield } \\ \mathrm{RR}= & \text { Retention ratio } \\ \mathrm{U}_{\mathrm{T}}= & \text { Stochastic Error Term } \\ \text { Apriori, } & \text { it was expected that } \mathrm{b}_{1} \geq 0, \mathrm{~b}_{2} \leq 0\end{array}$

Decision Rule:

Accept $\mathrm{H}_{01}$ if $\mathrm{t}$-stat of $\mathrm{b}_{1}$ is greater than 2 , if not reject.

Accept $\mathrm{H}_{\mathrm{o} 2}$ if $\mathrm{t}$-stat of $\mathrm{b}_{2}$ is greater than 2 , if not reject. 


\section{Data Presentation}

\section{DATA PRESENTATION AND ANALYSIS}

In this section, the necessary data collected were presented, analyzed and interpreted in order to arrive at cogent conclusions. The relevant data utilised here are data on the following variables:

- Market price

- Dividend yield

- Retention ratio

All of these data are as seen in appendix 1.

\section{Analysis of Data}

The data presented in appendix 1 was analysed using eviews 7 statistical software. The first test done was the ADF unit root test in order to test for stationarity of the data.regression. The result of this test is as shown in appendix 2 from the result it can be seen that the variables had unit root. Therefore there was need to difference the variables in an attempt to cater to the unit root. The result of the unit root test carried out on the modified variables is as seen in appendix 3 . The results showed that the variables were now stationary. This was due to the fact that the calculated t-statistic was less that the tabulated for all the variables. Furthermore their probabilities were all less than 0.05 which is the bench mark. Using the modified variables for the regression, the results retrieved are as seen in appendix 4. From the results it can be seen that the coefficients all have the expected apriori signs. Furthermore, they are all significant judging from the level of their t-statistics and probabilities. The adjusted $\mathrm{R}^{2}$ value of 0.92 shows that approximately $92 \%$ of the variations in the dependent variable are explained by the independent variables utilised. This is a good fit. This implied that the null forms of both hypotheses were rejected and the alternate forms accepted.

Thus, it can be seen, based on the results that dividend yield has a significantly positive effect on positive effect on the share price while retained earnings had a significantly negative effect on share price.

\section{SUMMARY AND FINDINGS, CONCLUSION AND RECOMMENDATION Summary of Findings}

This research work was carried out in order to ascertain the impact of dividend policy on share price valuation of Nigerian banks. In order to present a solid basis for this work, theoretical literature relating to this study were reviewed.

At the empirical level, two tests were carried out in order to ensure reliability of the results obtained. These were;

1. $\mathrm{ADF}$

2. Ordinary least squares method

The tests carried out revealed major findings as regards the objectives of the study. Dividend yield was found to have a significantly positive effect on share price while retention ratio was found to have a significantly negative effect on it.

\subsection{Conclusions}

Based on the analysis of the results, it was revealed that dividend policy indeed had a positive effect on shareholders wealth. This result conforms to the work of Pandey [24] who posits that dividends are payments made by organisation to shareholders usually after a company earns a profit. 
Therefore it can be concluded that dividend payout is a sure way of stimulating investment in the banks. This is due to the fact that it was established in this paper that shareholder have a preference for dividend income rather than capital gain as seen by the negative effect of retention ratio on share price. Most shareholders will thus feel uneasy if the banks they have invested in retain all of their profit after tax.

Furthermore, taking a look at the data showed that there were fluctuations when it came to dividend payments over the years. This must have been due to the prevailing economic conditions and government regulations. However the adoption of $100 \%$ dividend payout is not advised because the economic condition might become so harsh that the bank might suddenly find itself in dire need of funds.

Therefore, it is important to decide on an optimal dividend policy that will suit the needs of the bank. This decision is not one to be made solely by the board of directors. The shareholders should be given recognition since they are directly affected by the policy. If this is done and other factors considered too, an optimum decision concerning dividend policy could be reached which would help in ensuring the growth and development of the banks and ultimately affects the fortunes of, the Nigerian economy positively.

\subsection{Recommendations}

Based on the study and conclusions, this section profers recommendations which will be relevant to, banks, students, researchers etc. Dividend decision of corporate organization like banks separates the company's net earnings between dividend payout to shareholders and retained earnings. Board of directors, in making this decision must seek optimally in these separations.

Due to the several factors affecting dividend policy such as legal constraints, funding needs, control issue, debt obligation, investment opportunity, inflation, shareholders expectations etc good planning must be put in place. A balance must be struck by management between longterm financing and wealth maximization decision in an optimum manner.

A dividend policy, which is consistent with high dividend payout, is a clear signal of growth opportunities of the particular industry and as such shareholders can re-invest the funds in the industries and this provides opportunities for expansion in the future. This is not an implication that low dividend paying banks are not doing well and also not an implication that high dividend payment are always an indication of high performances (the dividends could actually be paid out of past years reserves.)

In summary therefore, the following recommendations are given;

- Banks should ensure that they have a good and robust dividend policy in place. This will enhance their profitability and attract investments to the organizations.

- Regular update of records of shareholders including their next-of-kin to should be made to avoid a deliberate diversion or undue retention of unclaimed dividend warrants.

- A more stringent level condition should be established to compel directors to only invest in profitable ventures, report the utilization of retention earnings through notes to the accounts.

- Government should set up a body that will help to manage unclaimed dividends and also ensure that situations that give rise to such are minimized.

If the above recommendations are followed exactly, this will be to the overall benefit of the banks and the nation at large. 


\section{REFERENCES}

Adefila, J.J., Oladapo, J.A. \& Adeoti, J.O. (2004). The effect of dividend policy on the market price of shares in Nigeria: case study of fifteen quoted companies. Retrieved from http://unilorin.edu.ng/publications/adeotijo/THE\%20EFFECT\%200F\%20DIVIDEND\%20POLICY.pdf

Adelegan, 0. (2003). The impact of growth prospect, leverage and firm size of dividend behavior of corporate firms in Nigeria. The centre for econometric and allied research UI, Nigeria

Adelegan, O.J. (2009). Price reactions to dividend announcements on the Nigerian stock market. AERC Research Paper 188, African Economic Research Consortium, Nairobi

Agrawal and Jayaraman (2004): Mechanism of dividend payment and leverage policy. Journal of accounting research 21(2)

Asem, E. (2009). Dividends and price momentum. Journal of banking \& finance. 33(3), pp. 486-494.

Baker, M. and Wurgler, J. (2004). A catering theory of dividends. Journal of finance, 59(3), 1125-1165

Benaruzi, S.O. (1997). Do changes in dividends signal the future or the past? Journal of finance, 52 (3), 1007-1032.

Chowdhury, T. A. \& Ahmed, K. (2009). Performance evaluation of selected private commercial banks in Bangladesh, International journal of business and management, vol. 4, no. 4, pp. 86-97

Eriki, O. and Okafor, C. (2002). Dividend and stock prices on the Nigerian stock exchange. Accounting: The Nigeria perspective (Ed)

Frankfurter, G. M., and Wood, B.G., (1997), the evolution of corporate dividend policy, Journal of financial education $23,16-33$.

Gordon, M. J., (1963). Optimal investment and financing policy, Journal of finance, 18, 264-272

Ghosh and Subrata (2006) Management and performance measurement in organization. Journal of business, London

Hashemijoo, M., Ardekani, A.M. \& Younesi, N. (2012). The impact of dividend policy on share price volatility in the Malaysian stock market. Journal of business studies quarterly, 4(1), pp. 119-129.

Holder, M., Langrehr, F. and Hexter, J. (1998). Dividend policy determinants: An investigation of the influences of stakeholder theory. Financial management, 27, 73-82.

Kempner .T. (1980) A handbook of management, Penguin books, United Kingdom

Kwan, C.Y. (2012). Effective market test of the information content of dividend announcements: critique and extension", Journal of finance and quantitative analysis. 16, 193-206

Lintner, J. (1956). Distribution of incomes of corporations among dividend retained earnings and taxes, American economic review. Vol. 46.

Lintner J. (1962). Dividend earning leverage stock price and the supply of capital to corporations. The review of economic and statistics.

Litzenberger, R. H. and Ramaswamy, K. (1979), the effect of personal taxes and dividends on capital asset prices, Journal of financial economics, 7, 163-195

Miller, M. H. and Modigliani, F. (1961). Dividend policy, growth, and the valuation of shares. American economic review, 48 (3), 261-297.

Miller, M. H. and Rock, K. (1985). Dividend policy under asymmetric information. The Journal of finance, 40 (4), $1031-1051$

Murhadi, W.R. (2008). Study on dividend policy: Antecedent and its impact on share price. Journal of manajemen \& kewirausahaan, 9(1), 1-29

Oyejide, T. A. (1978). Company dividend policy in Nigeria: An empirical analysis. The Nigerian journal of economic and social studies, 18(2): 179-194.

Pandey, I.M. (2005). Financial management (9th Edition). Vikas publishing house PVT Ltd 
Duke, S.B., Ikenna, N. D., \& Nkamare, S. E. (2015). Impact of Dividend Policy on Share Price Valuation in Nigerian Banks. Archive of Business Research, 3(1) 156-170

Petty, W. J. (2007). Basic financial management, London, Englewood cliffs

Quickmba (n.d.). Marketing research. Retrieved from http://www.quickmba.com/marketing

Shabibi, B., and Ramesh, G. (2011). An empirical study on the determinants of dividend Holt, Rinehart

Uwuigbe, U., Jafaru, J. \& Ajayi, A. (2012). Dividend policy and firm performance: A study of listed firms in Nigeria. Journal of accounting and management information systems.11 (3), 442-454

Weston, J.F. and Brigham, E.F. (1972). Managerial finance. 4th Ed., NY: Holt, Rinehart \& Winston.

Zulfiqar, A., and Asgher, M (2011). Impact of dividend policy on stock return: empirical evidence from equity market of Pakistan. Far East journal of psychology andbusiness. 45-52

\section{Appendix 1}

Data on variables used (GTB and UBA)

\begin{tabular}{|c|c|c|c|c|c|c|c|}
\hline $\begin{array}{c}\text { YEAR } \\
\text { GTB }\end{array}$ & $\begin{array}{c}\text { PS } \\
\text { (kobo) }\end{array}$ & $\begin{array}{c}\text { DS } \\
\text { (kobo) }\end{array}$ & $\begin{array}{c}\text { TE } \\
(\mathbf{N}, \mathbf{b n})\end{array}$ & $\begin{array}{c}\text { TD } \\
(\mathbf{N}, \mathbf{b n})\end{array}$ & $\begin{array}{c}\text { RE } \\
(\mathbf{N}, \mathbf{b n})\end{array}$ & $\begin{array}{c}\text { DY(\%) = } \\
\text { (DS X } \\
100) / P S\end{array}$ & $\begin{array}{c}\text { RR (\%) = } \\
\text { (TE- } \\
\text { TD)X100/TE }\end{array}$ \\
\hline \multicolumn{8}{|l|}{2003} \\
\hline Q1 & 49.05 & 86.52 & 3.08 & 2.41 & 0.55 & 174.66 & 22.15 \\
\hline Q2 & 48.14 & 83.07 & 3.06 & 2.33 & 0.49 & 169.33 & 24.95 \\
\hline Q3 & 48.32 & 60.76 & 3.14 & 1.58 & 0.04 & 124.4 & 50.28 \\
\hline Q4 & 50 & 60 & 3.2 & 1.5 & 0 & 120 & 53.13 \\
\hline \multicolumn{8}{|l|}{2004} \\
\hline Q1 & 51.74 & 59.56 & 3.26 & 1.44 & -0.03 & 116.08 & 55.51 \\
\hline Q2 & 53.88 & 59.56 & 3.33 & 1.38 & -0.06 & 112.35 & 57.85 \\
\hline Q3 & 75.88 & 69.02 & 4.05 & 1.32 & -0.05 & 91.41 & 67.18 \\
\hline Q4 & 77 & 70 & 4.1 & 1.4 & 0 & 90.91 & 65.85 \\
\hline \multicolumn{8}{|l|}{2005} \\
\hline Q1 & 77.34 & 70.66 & 4.16 & 1.5 & 0.06 & 91.14 & 64.22 \\
\hline Q2 & 77.16 & 71.13 & 4.2 & 1.63 & 0.13 & 91.82 & 62.01 \\
\hline Q3 & 62.03 & 74.78 & 5.05 & 3.46 & 1.23 & 120.72 & 32.64 \\
\hline Q4 & 60 & 76 & 5.3 & 3.7 & 1.4 & 126.67 & 30.19 \\
\hline \multicolumn{8}{|l|}{2006} \\
\hline Q1 & 58.53 & 77.37 & 5.56 & 3.91 & 1.51 & 132.12 & 28.69 \\
\hline Q2 & 57.22 & 79.01 & 5.85 & 4.12 & 1.63 & 138.02 & 27.68 \\
\hline Q3 & 50.39 & 94.47 & 8.59 & 5.62 & 1.48 & 187.53 & 33.1 \\
\hline Q4 & 50 & 95 & 8.7 & 5.7 & 1.2 & 190 & 34.48 \\
\hline \multicolumn{8}{|l|}{2007} \\
\hline Q1 & 49.59 & 94.89 & 8.86 & 5.78 & 1.01 & 191.03 & 35.64 \\
\hline Q2 & 49.21 & 94.33 & 8.98 & 5.84 & 0.77 & 191.03 & 36.8 \\
\hline Q3 & 47.89 & 77.33 & 11.97 & 6.12 & 0.83 & 161.08 & 50.2 \\
\hline Q4 & 48 & 75 & 13 & 6.2 & 1.6 & 156.25 & 52.31 \\
\hline \multicolumn{8}{|l|}{2008} \\
\hline Q1 & 48.21 & 73.38 & 14.08 & 6.34 & 2.52 & 152.58 & 54.14 \\
\hline Q2 & 48.47 & 71.88 & 15.35 & 6.5 & 3.65 & 149.01 & 56.08 \\
\hline Q3 & 54 & 68.66 & 27.44 & 9.16 & 16.91 & 127.74 & 66.63 \\
\hline Q4 & 55 & 70 & 28 & 9.6 & 18 & 127.27 & 65.71 \\
\hline \multicolumn{8}{|l|}{2009} \\
\hline Q1 & 55.85 & 71.51 & 28.27 & 10.03 & 18.74 & 127.53 & 64.46 \\
\hline Q2 & 62.25 & 95.08 & 24.25 & 14.25 & 19.32 & 151.27 & 40.88 \\
\hline Q3 & 62.25 & 97.66 & 24.01 & 14.64 & 19.14 & 156.08 & 38.92 \\
\hline Q4 & 62 & 100 & 24 & 15 & 19 & 161.29 & 37.5 \\
\hline \multicolumn{8}{|l|}{2010} \\
\hline Q1 & 61.56 & 101.58 & 24.38 & 15.32 & 19.06 & 165.67 & 36.96 \\
\hline Q2 & 60.88 & 102.86 & 25.01 & 15.61 & 19.17 & 170.3 & 36.99 \\
\hline
\end{tabular}




\begin{tabular}{|c|c|c|c|c|c|c|c|}
\hline Q3 & 50.78 & 101.52 & 35.85 & 17.69 & 21.68 & 200.44 & 49.95 \\
\hline Q4 & 50 & 100 & 37 & 18 & 22 & 200 & 51.35 \\
\hline \multicolumn{8}{|l|}{2011} \\
\hline Q1 & 49.56 & 98.72 & 38.06 & 18.37 & 22.36 & 198.89 & 52.19 \\
\hline Q2 & 49.32 & 97.23 & 39.03 & 18.78 & 22.71 & 196.72 & 52.77 \\
\hline Q3 & 51.71 & 84.31 & 49.83 & 23.44 & 27.95 & 163.11 & 53.5 \\
\hline Q4 & 52 & 84 & 52 & 24 & 29 & 161.54 & 53.85 \\
\hline \multicolumn{8}{|l|}{2012} \\
\hline Q1 & 52.08 & 84.37 & 54.33 & 24.57 & 30.13 & 162.02 & 54.4 \\
\hline Q2 & 52.08 & 85.16 & 56.93 & 25.13 & 31.38 & 163.58 & 55.11 \\
\hline Q3 & 50.22 & 106.52 & 82.94 & 31.12 & 44.68 & 212.33 & 62.24 \\
\hline Q4 & 50 & 110 & 85 & 32 & 46 & 220 & 62.35 \\
\hline \multicolumn{8}{|l|}{2013} \\
\hline Q1 & 49.87 & 113.31 & 86.45 & 32.94 & 47.13 & 227.03 & 62.05 \\
\hline Q2 & 49.78 & 116.74 & 87.55 & 33.94 & 48.15 & 234.19 & 61.47 \\
\hline Q3 & 49.93 & 151 & 86.69 & 44.71 & 54.46 & 302.24 & 48.4 \\
\hline Q4 & 50 & 155 & 86 & 46 & 55 & 310 & 46.51 \\
\hline \multicolumn{8}{|l|}{$\begin{array}{l}\text { YEAR } \\
\text { UBA }\end{array}$} \\
\hline \multirow{2}{*}{\multicolumn{8}{|c|}{$\begin{array}{l}\text { UBA } \\
2003\end{array}$}} \\
\hline & & & & & & & \\
\hline Q1 & 50.31 & 31.36 & 1.52 & 0.41 & 0.48 & 62.02 & 71.25 \\
\hline Q2 & 50.61 & 32.71 & 1.63 & 0.4 & 0.5 & 64.05 & 73.17 \\
\hline Q3 & 50.55 & 43.94 & 2.84 & 0.45 & 0.75 & 86.64 & 83.56 \\
\hline Q4 & 50 & 45 & 3 & 0.5 & 0.81 & 90 & 83.33 \\
\hline \multicolumn{8}{|l|}{2004} \\
\hline Q1 & 49.44 & 45.9 & 3.14 & 0.55 & 0.88 & 93.08 & 82.81 \\
\hline Q2 & 48.76 & 46.75 & 3.29 & 0.62 & 0.96 & 96.31 & 81.93 \\
\hline Q3 & 42.19 & 50.22 & 4.14 & 1.41 & 2 & 118.82 & 65.4 \\
\hline Q4 & 42 & 50 & 4.1 & 1.5 & 2.15 & 119.05 & 63.41 \\
\hline \multicolumn{8}{|l|}{2005} \\
\hline Q1 & 42.06 & 50.1 & 4.09 & 1.57 & 2.26 & 119.25 & 62.1 \\
\hline Q2 & 42.32 & 50.13 & 4.06 & 1.63 & 2.37 & 118.86 & 60.94 \\
\hline Q3 & 49.21 & 57.25 & 4.53 & 1.83 & 2.36 & 116.92 & 61.53 \\
\hline Q4 & 50 & 60 & 4.9 & 1.8 & 2.13 & 120 & 63.27 \\
\hline \multicolumn{8}{|l|}{2006} \\
\hline Q1 & 50.64 & 62.86 & 5.32 & 1.78 & 1.95 & 123.62 & 64.87 \\
\hline Q2 & 51.21 & 66.23 & 5.83 & 1.76 & 1.72 & 128.28 & 66.8 \\
\hline Q3 & 56.13 & 98.5 & 11.18 & 1.72 & 0.91 & 174.5 & 84.1 \\
\hline Q4 & 57 & 100 & 11.5 & 1.8 & 1.34 & 175.44 & 84.35 \\
\hline \multicolumn{8}{|l|}{2007} \\
\hline Q1 & 57.94 & 100.66 & 11.88 & 1.97 & 1.99 & 174.7 & 84.01 \\
\hline Q2 & 58.99 & 100.57 & 12.17 & 2.18 & 2.81 & 172.45 & 83.1 \\
\hline Q3 & 69.23 & 86.68 & 18.01 & 6.31 & 15.19 & 126.18 & 65.38 \\
\hline Q4 & 70 & 86 & 19.8 & 7.1 & 16.86 & 122.86 & 64.14 \\
\hline \multicolumn{8}{|l|}{2008} \\
\hline Q1 & 70.46 & 86.11 & 21.56 & 7.86 & 18.19 & 121.63 & 63.33 \\
\hline Q2 & 70.75 & 86.75 & 23.61 & 8.69 & 19.5 & 121.55 & 62.93 \\
\hline Q3 & 67.04 & 99.65 & 40.08 & 16.18 & 25.6 & 148.24 & 60.32 \\
\hline Q4 & 66 & 100 & 40 & 16.7 & 25.13 & 151.52 & 58.25 \\
\hline \multicolumn{8}{|l|}{2009} \\
\hline Q1 & 64.98 & 99.2 & 39.3 & 16.99 & 24.53 & 152.73 & 55.32 \\
\hline Q2 & 63.87 & 97.84 & 37.98 & 17.16 & 23.66 & 153.41 & 51.73 \\
\hline Q3 & 51.43 & 65.31 & 14.79 & 13.84 & 11.77 & 127.37 & 3.94 \\
\hline Q4 & 50 & 60 & 12.8 & 13 & 10.96 & 120 & -1.56 \\
\hline
\end{tabular}


Duke, S.B., Ikenna, N. D., \& Nkamare, S. E. (2015). Impact of Dividend Policy on Share Price Valuation in Nigerian Banks. Archive of Business Research, 3(1) 156-170

\begin{tabular}{|r|rrrrrrr|r}
\hline $\mathbf{2 0 1 0}$ & & & & & & & \\
Q1 & 48.81 & 55.2 & 11.36 & 12.22 & 10.27 & 112.63 & -5.31 \\
Q2 & 47.67 & 50.24 & 10.32 & 11.38 & 9.81 & 104.37 & -8.7 \\
Q3 & 41.89 & 8.25 & 4.16 & 2.98 & 3.97 & 19.26 & -5.86 \\
Q4 & 42 & 5 & 2.2 & 2.2 & 1.84 & 11.9 & 0 \\
$\mathbf{2 0 1 1}$ & & & & & & & \\
Q1 & 42.2 & 2.5 & 0.21 & 1.6 & -0.18 & 6.51 & 6.11 \\
Q2 & 42.58 & 0.48 & -2.21 & 1.07 & -2.62 & 2.13 & 13.44 \\
Q3 & 49.37 & -1.12 & -18.09 & -0.22 & -18.12 & -2.23 & 93.98 \\
Q4 & 50 & 0 & -16.4 & 0 & -16.39 & 0 & 100 \\
$\mathbf{2 0 1 2}$ & & & & & & & \\
Q1 & 50.39 & 0.56 & -13.72 & 0.12 & -13.69 & 1.09 & 104.02 \\
Q2 & 50.68 & 1.21 & -9.97 & 0.28 & -9.92 & 2.36 & 106.73 \\
Q3 & 50.17 & 1.62 & 42.7 & 0.5 & 42.7 & 3.23 & 100.79 \\
Q4 & 50 & 0 & 47.4 & 0 & 47.38 & 0 & 100 \\
$\mathbf{2 0 1 3}$ & & & & & & & \\
Q1 & 49.93 & -2.25 & 50.42 & -0.73 & 50.4 & -4.49 & 100.78 \\
Q2 & 49.87 & -5 & 52.64 & -1.63 & 52.61 & -9.99 & 102.13 \\
Q3 & 49.96 & -44.75 & 48.33 & -14.76 & 48.3 & -89.5 & 131.3 \\
Q4 & 50 & -50 & 46.5 & -16.5 & 46.48 & -100 & 135.48 \\
\hline
\end{tabular}

Source: Annual reports of various years of both banks.

NB: $\mathrm{PS}=$ price per share, $\mathrm{DS}=$ dividend per share, $\mathrm{TE}=$ total earnings, $\mathrm{TD}=$ total dividend, $\mathrm{RE}=$ retained earnings, $\mathrm{DY}=$ dividend yield, $\mathrm{RR}=$ retention ratio 


\section{Appendix 2}

ADF Test on Variables

\begin{tabular}{|c|c|c|c|c|c|c|}
\hline & \multicolumn{3}{|c|}{ UBA } & \multicolumn{3}{c|}{ GTBANK } \\
\hline VARIABLE & SHARE & DIVIDEND & RETENTION & SHARE & DIVIDEND & RETENTION \\
& MARKET & YIELD (DY) & RATIO (RR) & MARKET & YIELD (DY) & RATIO (RR) \\
& PRICE (MP) & & & PRICE (MP) & & \\
\hline T-TAB (1\%) & -4.5074 & $-\mathbf{0 . 2 4 2 2}$ & 0.5134 & 2.8172 & 3.2615 & 2.5112 \\
\hline T-TAB (5\%) & $-\mathbf{3 . 6 3 2 2}$ & $-\mathbf{0 . 1 9 8 2}$ & 0.9244 & 3.2511 & 2.1524 & 1.2653 \\
\hline T-TAB (10\%) & $-\mathbf{- 3 . 5 8 2 2}$ & $\mathbf{0 . 1 5 2 3}$ & 0.8152 & 1.7844 & $\mathbf{0 . 8 1 9 2}$ & $\mathbf{0 . 2 5 6 3}$ \\
\hline T-CAL & $-\mathbf{2 . 6 2 2 3}$ & $\mathbf{0 . 8 2 3 3}$ & 1.9282 & 3.7388 & 4.9087 & 2.9811 \\
\hline PROB. & $\mathbf{0 . 2 1 4 4}$ & $\mathbf{0 . 0 9 1 3}$ & $\mathbf{0 . 1 8 2 4}$ & $\mathbf{0 . 2 4 3 3}$ & $\mathbf{0 . 0 9 0 9}$ & $\mathbf{0 . 1 2 8 7}$ \\
\hline
\end{tabular}

Source: E-view 7

\section{Appendix 3}

ADF Test on Differenced Variables

\begin{tabular}{|c|c|c|c|c|c|c|}
\hline & \multicolumn{3}{|c|}{ UBA } & \multicolumn{3}{c|}{ GTBANK } \\
\hline \multirow{2}{*}{ VARIABLE } & SHARE & DIVIDEND & RETENTION & SHARE & DIVIDEND & RETENTION \\
& MARKET & YIELD (DY) & RATIO (RR) & MARKET & YIELD (DY) & RATIO (RR) \\
& PRICE (MP) & & & PRICE (MP) & & \\
\hline T-TAB (1\%) & -2.5242 & 2.6252 & 0.6252 & 3.6253 & 2.1726 & 4.7363 \\
\hline T-TAB (5\%) & -2.1524 & 1.9511 & 0.1852 & 2.8722 & 2.7339 & 1.6253 \\
\hline T-TAB (10\%) & -3.5246 & 2.7262 & 0.8172 & 1.1212 & 0.6171 & 0.5266 \\
\hline T-CAL & -5.6223 & 1.4232 & 0.1472 & 1.0022 & 0.0622 & 0.3121 \\
\hline PROB. & $\mathbf{0 . 0 1 4 4}$ & $\mathbf{0 . 0 4 1 3}$ & $\mathbf{0 . 0 0 2 4}$ & $\mathbf{0 . 0 0 3 3}$ & $\mathbf{0 . 0 1 0 1}$ & $\mathbf{0 . 0 0 8 7}$ \\
\hline
\end{tabular}

Source: E-views 7 


\section{Appendix 4 \\ Ordinary Least Squares Regression}

Date: 12/17/14 Time: 09:09

Sample: 19942013

\begin{tabular}{lllll}
\hline \hline Variable & Coefficient & Std. Error & t-Statistic & Prob. \\
\hline \hline C & 0.1833 & 0.025365 & 2.415267 & 0.0312 \\
D(DY) & 0.342523 & 0.016227 & 2.525230 & 0.0231 \\
$D(R R)$ & -0.241551 & 0.033725 & 3.615262 & 0.0077 \\
\hline \hline R-squared & 0.947403 & Mean dependent var & $1.47 \mathrm{E}+10$ \\
Adjusted R-squared & 0.921353 & S.D. dependent var & $1.76 \mathrm{E}+10$ \\
S.E. of regression & $1.36 \mathrm{E}+10$ & Akaike info criterion & 19.60647 \\
Sum squared resid & $4.43 \mathrm{E}+21$ & Schwarz criterion & 49.75045 \\
Log likelihood & -66.6874 & Hannan-Quinn criter. & 43.64929 \\
F-statistic & 96.715649 & Durbin-Watson stat & 1.892685 \\
Prob(F-statistic) & 0.000811 & & & \\
\hline \hline
\end{tabular}

\section{Source: Eviews 7}

